\title{
Characterisation of $\beta$-lactoglobulin nanoparticles and their binding to caffeine
}

Article

Accepted Version

Creative Commons: Attribution-Noncommercial-No Derivative Works 4.0

Guo, Y., Harris, P., Kaur, A., Pastrana, L. and Jauregi, P. (2017) Characterisation of $\beta$-lactoglobulin nanoparticles and their binding to caffeine. Food Hydrocolloids, 71. pp. 85-93. ISSN 0268-005X doi: https://doi.org/10.1016/j.foodhyd.2017.04.027 Available at https://centaur.reading.ac.uk/71055/

It is advisable to refer to the publisher's version if you intend to cite from the work. See Guidance on citing.

Published version at: http://dx.doi.org/10.1016/j.foodhyd.2017.04.027

To link to this article DOI: http://dx.doi.org/10.1016/j.foodhyd.2017.04.027

Publisher: Elsevier

All outputs in CentAUR are protected by Intellectual Property Rights law, including copyright law. Copyright and IPR is retained by the creators or other copyright holders. Terms and conditions for use of this material are defined in the End User Agreement.

\section{www.reading.ac.uk/centaur}

\section{CentAUR}

Central Archive at the University of Reading 
Reading's research outputs online 


\section{Characterisation of $\beta$-Lactoglobulin nanoparticles and their binding to caffeine}

${ }^{1}$ Yuchen Guo ${ }^{2}$ Peter Harris, ${ }^{3}$ Lorenzo Pastrana, ${ }^{1 *}$ Paula Jauregi

${ }^{1}$ Department of Food and Nutritional Sciences. University of Reading, Whiteknights, Reading, RG6 6AP, United Kingdom.

${ }^{2}$ Centre for Advanced Microscopy, University of Reading, Whiteknights, Reading, RG6 6AP, United Kingdom

${ }^{3}$ INL - International Iberian Nanotechnology Laboratory, Av. Mestre José Veiga s/n, 4715-330 Braga Portugal

*Corresponding author.

E-mail address: p.jauregi@reading.ac.uk (P.Jauregi)

Address: Department of Food and Nutritional Sciences. University of Reading, Whiteknights, Reading, RG6 6AP, United Kingdom.

Telephone: $+44(0) 1183788728$

1 ABSTRACT

2 The production of $\beta$ - $\mathrm{Lg}$ nanoparticles by a simple heat-induced denaturation method

3 without the need to add chemicals was performed at different conditions of $\mathrm{pH}$, and

4 temperature of denaturation. Optimum conditions were set as $0.2 \% \beta-\mathrm{Lg}, \mathrm{pH} 6$ and

5 simply heating at $75^{\circ} \mathrm{C}$ for 45 minutes. At these conditions, a monodisperse solution

6 with colloidal stability was obtained and the yield of aggregation was over $90 \%$. Shape

7 and size of nanoparticles were determined by Dynamic Light Scattering and by electron

8 microscopy. A monodisperse particle size distribution of spherical shape particles

9 (200nm-300nmin diameter) was obtained. The stability of the aggregates towards

10 various types of dissociating buffers was studied. Sodium dodecyl sulphate (SDS) and

11 urea had a strong effect on the size of the nanoparticles, while 2-Mercaptoethanol and

12 Dithiothreitol (DTT) had no significant effect. Therefore hydrogen bonding and 13 hydrophobic interactions were the predominant interactions responsible for the 
microstructure. Maximum yield of caffeine encapsulation of $13.54 \%$ was obtained at caffeine to the $\beta$-Lg molar ratio of 50:1. Rapid nanoparticle degradation and increase in polydispersity during the incubation of $\beta-\mathrm{Lg}$ nanoparticles at simulating stomach conditions was observed due to enzymatic attack. Nevertheless, little release of entrapped caffeine was noted. Total release was achieved at intestinal conditions. Finally, the adsorption of caffeine to both native and denatured $\beta$-Lg followed a Langmuir adsorption isotherm model and caffeine had three times more affinity for partially denatured $\beta$ - Lg in nanoparticles than for native protein.

Keywords: Caffeine; nanoparticles; $\beta$-Lactoglobulin; simulated digestion, encapsulation.

\section{Introduction}

Whey is the principal by-product of cheese manufacturing and it represents $85-95 \%$ of the initial volume of processed milk with high Chemical oxygen demand (COD) and Biochemical oxygen demand (BOD) values hence its disposal would have a negative environmental impact. The total world production of liquid cheese whey in 2008 was in the region of 187 million metric tons and of this 3.2 million metric tons were industrially utilised and processed into higher added value products such as, whey powder, whey proteins concentrates and whey protein fractions (Afferstsholt \& Palmer, 2009; C. Baldasso , T.C. Barros, \& Tessaro, 2011); the remaining whey is used for animal feed, fertilisers, baby milk powder and some it is just dumped. Whey is a valuable source of proteins (about $0.8-0.9 \%$ protein) with high nutritional value and additional biological properties as well as numerous functional properties such as gelation, emulsifying and foaming properties(Jauregi \& Welderufael, 2010). The major whey protein, beta-lactoglobulin $(\beta-\mathrm{Lg})$ which comprises $51 \%(\mathrm{w} / \mathrm{w})$ of total protein has very interesting aggregation properties which have been exploited for its application as an encapsulant (Chen, Remondetto, \& Subirade, 2006; H. J. Giroux, Houde, \& Britten, 2010; Jones, Lesmes, Dubin, \& McClements, 2010). This protein is predominantly dimeric at physiological conditions, but dissociates to a monomer at 
about pH 3 (Tauliera \& Chalikiana, 2001); its isoelectric point (pI) is 5.13. Four out of its five cysteine residues form two disulfide bridges leaving a free reactive thiol group that appears to be responsible for the formation of covalent aggregates upon heating (Sawyer, 2002). Also $\beta$-Lg possess a hydrophobic pocket that when exposed by, for example, heat denaturation forms aggregates by hydrophobic interactions. These aggregation properties can be manipulated by changing temperature, $\mathrm{pH}$, and ionic strength. Under prolonged heating at low $\mathrm{pH}$ and low ionic strength, a transparent `finestranded' gel is formed, in which the protein molecules assemble into long stiff fibers and also can produce nanoparticles (Ko \& Gunasekaran, 2006).

Food protein-based nanoparticles are of great interest because they are Generally Recognised as Safe (GRAS), easy to prepare, no need for chemical cross-linking agents during preparation, better control over size distributions (Chen et al., 2006; Gunasekaran, Ko, \& Xiao, 2006). $\beta$-Lg is able to aggregate forming nanoparticles that have some technological advantages as an encapsulant for bioactives; among others: inexpensive, food grade and non-toxic material, capable of solubilizing and protecting hydrophobic biologically active molecules in aqueous media as well as capable of retaining sensory qualities, and promote bioavailability of hydrophobic biologically active molecules. In this sense, when electrically charged, $\beta$ - $\mathrm{Lg}$ is also able to ion binding and electrostatic complex formation, self and co-assembly and covalent conjugation (Livney, 2010).

In previous works, $\beta-\mathrm{Lg}$ nanoparticles have been applied as carriers for a range of nutraceutical products such as, polysaccharides, pectin, carageenan or chitosan (Chen \& Subirade, 2005; Jones et al., 2010; Ron, Zimet, Bargarum, \& Livney, 2010; Zimet \& Livney, 2009) where $\beta$-Lg forms complexes with each of these products. The complexity of method and materials used for the production of such complexes hinders the possibility for scaling up production. On the other hand, simple production steps such as desolvation with ethanol can produce nanoparticles without application of heat, thus making it very feasible for heat-labile bioactive components (Gulseren, Fang, \& 
Corredig, 2012). Nonetheless, usage of organic solvents for food application is still the major drawback for this method (Nicolai, Britten, \& Schmitt, 2011).

Caffeine is an amphiphilic alkaloid drug that has a strong bioactivity acting as a stimulant drug of the central nervous system. For this reason is considered the most popular legal stimulant consumed in the world, mainly in the form of coffee and tea infusion (Gilbert, 1984). In the last years, several energy drinks containing caffeine have been launched to the market having a great success and customer acceptation (Somogyi, 2010). Unfortunately, caffeine has very bitter taste and unpleasant aftertaste limiting or even excluding their use from many food and drink formulations. Encapsulation of caffeine enables bitterness masking and it can be easily added to food and drink products without changing the flavour or increasing the bitterness level. In addition, encapsulation could provide protection against harsh processing conditions and controlled release.

The aim of this study is to investigate the production of $\beta$ - $\mathrm{Lg}$ nanoparticles by a simple heat-induced denaturation method without the need to add chemicals and/or other reagents and to investigate their application to the encapsulation of caffeine. Particles were characterised in terms of size by Dynamic Light Scattering technique, fluorescence and by electron microscopy. Stability to buffers was examined as an indirect measurement of the internal forces responsible for the molecular network within the particles. This led to an improved understanding of the mechanism of aggregate formation and their interactions with caffeine.

\section{Materials and Methods}

\subsection{Materials}

$\beta$-lactoglobulin $(\beta$-Lg) from bovine milk, $\geq 90 \%$ PAGE lyophilised powder was purchased from Sigma-Aldrich (United Kingdom) for all the experiments. The material used for encapsulation was caffeine (99\% purity) obtained also from Sigma-Aldrich (United Kingdom). 


\subsection{Methods}

103

\subsubsection{Preparation of $\beta$-lactoglobulin nanoparticle}

The $\beta$-lg powder was dispersed in deionized water to make $50 \mathrm{ml} 0.2 \% \mathrm{w} / \mathrm{v} \beta$-Lg stock solution and it was stirred magnetically for about two hours at room temperature. This stock solution was stored in a 50ml Falcon tube (VWR International, 525-0403, USA) at $4{ }^{\circ} \mathrm{C}$ over the whole night to complete hydration. In order to prevent the growth of microorganisms, 200 ppm sodium azide were added.

A $5 \mathrm{ml}$ sample from the $\beta$-Lg stock solution was added into $15 \mathrm{ml}$ a Falcon tube (VWR International, 5250401, USA) and after warming the sample up to room temperature, the $\mathrm{pH}$ was measured. Then the $\mathrm{pH}$ of the sample was adjusted to 6.0 (except when the $\mathrm{pH}$ effect was investigated) using a pH meter (Mettler Toledo, Switzerland) with $0.1 \mathrm{M}$ HCL and $0.1 \mathrm{M} \mathrm{NaOH}$. After this, the Falcon tube containing the sample was introduced into a water bath (Grant Instrument Ltd., Cambridge, United Kingdom) that had been previously heated at $75{ }^{\circ} \mathrm{C}$. The sample was left for 45 minutes at this temperature except when the effect of heat load was investigated. The temperature of the sample was monitored and it took about 12-14 minutes for the temperature in the samples to reach the water temperature $\left(75^{\circ} \mathrm{C}\right)$. After the set heating time samples were moved to an ice bath for 10 minutes to terminate incubation and the $\mathrm{pH}$ of the sample was measured. For experiments where $\mathrm{pH}$ effect (from 5.7 to 6.2) was investigated, nanoparticles were produced following procedure described above but initial $\mathrm{pH}$ of sample was changed. For experiments where temperature effect was investigated, samples were heated at $60{ }^{\circ} \mathrm{C}$ and $75^{\circ} \mathrm{C}$; all other conditions were kept constant $(0.2 \%$ w/w of $\beta-\mathrm{Lg}, \mathrm{pH} 6$ and heating time 75 minutes). For experiments where the heating time (heat load) effect was investigated, nanoparticles were produced following procedure described above at $0.2 \% \mathrm{w} / \mathrm{w}$ of $\beta$ - $\mathrm{Lg}, \mathrm{pH} 6$ and $75^{\circ} \mathrm{C}$ but at varying heating times: $15,25,35,45,55,65$ and 75 mins. 


\subsubsection{Preparation of caffeine encapsulated $\beta$-lactoglobulin nanoparticles}

133

The experiment on the encapsulation of caffeine was conducted only with $0.2 \%(\mathrm{w} / \mathrm{v})$ dispersions. Caffeine (99\% purity) was added to the $\beta$ - $\mathrm{Lg}$ dispersions prior to $\mathrm{pH}$ adjustment to obtain $10: 1,20: 1,50: 1,100: 1,200: 1$ caffeine to $\beta$-Lg molar ratios. A certain volume of stock caffeine solution $(10 \mathrm{mg} / \mathrm{ml})$ was mixed with protein samples to achieve 10:1, 20:1 caffeine to $\beta$-Lg molar ratios, respectively. The final protein concentration after $\mathrm{pH}$ adjustment and caffeine addition was $0.2 \%(\mathrm{w} / \mathrm{v})$. Caffeine powder was added into samples to obtain 50:1, 100:1, 200:1 caffeine to $\beta$-Lg molar ratios, respectively. Once caffeine was added to the $\beta$-Lg solution, the encapsulation method proceeded in the same way as the nanoparticle formation procedure described in section 2.2.1.

\subsubsection{Particle size distribution}

The $\mathrm{z}$-average hydrodynamic diameter of $\beta$ - $\mathrm{Lg}$ nanoparticles was measured by the dynamic light scattering technique using Zetasizer Nano Z (Malvern Instruments Inc., Malvern, United Kingdom) at $25 \pm 0.1^{\circ} \mathrm{C}$ and five measurements were taken for each sample. The measurement was determined by considering the refractive index of $\beta-\mathrm{Lg}$ as 1.45 and that of the dispersant medium (deionised water) as 1.33. The z-average mean was calculated from the intensity of light scattered from the nanoparticles, based on Stokes-Einstein equation, which assumes that all particles are spherical. Each sample was measured five times and the mean and standard deviation were determined. In some cases samples were diluted in order to operate at concentrations appropriate for DLS (as indicated by the machine). When samples were incubated with different dissociating buffers the refractive index of these buffers was taken into account: (i)10M urea, refractive index 1.370 (Warren \& Gordon, 1966) (ii) 0.1M Mercaptoethanol, refractive index 1.500 (Sigma-Aldrich, 2017), (iii) 1\% (w/v) SDS, refractive index 1.334 (Tumolo, Angnes, \& Baptista, 2004), (v) 0.1 M DTT, refractive index 1.576 (ChemBK, 2017). 


\subsection{4. $\quad \beta$-lactoglobulin aggregation}

163

164

165

The degree of thermal aggregation for $\beta$ - Lg was determined by separation of denatured $\beta$-Lg nanoparticles from native $\beta$-Lg using centrifugal ultrafiltration Vivaspin ${ }^{\circledR} 20$ (Sartorius Stedim Biotech, Germany) with 50kDa molecular weight cut-off membrane. To quantify the amount of native and aggregated $\beta-\mathrm{Lg}, 5 \mathrm{ml}$ of the heated $\beta$-Lg solution following the method described in section 2.2.1 was centrifuged at $2000 \mathrm{rpm}$ for 15 minutes to collect the retentate as well as the permeate; the retentate and permeate volumes were determined by weight. The concentration of the native $\beta$-Lg remained in permeate was determined by the bicinchoninic acid (BCA) method. In brief, $0.1 \mathrm{ml}$ of the permeate solution was added to $2 \mathrm{ml}$ of BCA working reagent (bicinchoninic acid and copper (II) sulphate pentahydrate), followed by incubation at $37^{\circ} \mathrm{C}$ for $30 \mathrm{~min}$. The reaction solution was measured at $562 \mathrm{~nm}$ in an Ultrospec ${ }^{\circledR} 1100$ pro UV-vis spectrophotometer (United Kingdom). The percentage of protein aggregated was determined by measuring the total protein in the permeate followed by mass balance on protein.

\subsubsection{Microscopy method}

Environmental Scanning Electron Microscopy (ESEM) was carried out on samples produced at the optimum conditions - $0.2 \% \beta$-lactoglobulin, $\mathrm{pH} 6.0$, at $75{ }^{\circ} \mathrm{C}$ for 45 minutes. The microscope used was a FEI Quanta 600, operated in environmental mode with a water vapour pressure of $822.46 \mathrm{~Pa}$, and a specimen temperature of $5^{\circ} \mathrm{C}$. The accelerating voltage was $20 \mathrm{kV}$. One drop of $\beta$-lactoglobulin nanoparticles sample was dispersed at the surface of the metal stub of the microscope and was dry at room temperature to ensure to some extent that moisture content was evaporated so that nanoparticles images were easier to capture.

\subsubsection{Fluorescence measurement of protein solutions}


The degree of $\beta$-Lg conformational changes on fluorescence emission of tryptophan (Trp) was accessed by fluorescence spectrophotometer with temperature controller (Varian Cary Eclipse, United Kingdom). Fluorescence spectra were obtained after excitation at $280 \mathrm{~nm}$, scanning an emission wavelength range between $290 \mathrm{~nm}$ to 510 $\mathrm{nm}$, using $5 \mathrm{~nm}$ excitation and emission slits wavelength. The data was collected by Cary Eclipse software version 2 (Varian Cary Eclipse, United Kingdom). Samples of native $\beta$ - Lg, heated $\beta$ - $\operatorname{Lg}$ nanoparticles, and caffeine loaded $\beta$-Lg nanoparticles were analysed in duplicate at a constant temperature of $20^{\circ} \mathrm{C}$.

\subsubsection{Stability against dissociating buffers}

All samples and buffers were filtered by $0.45 \mu \mathrm{m}$ filter before the incubation with dissociation buffers. $\beta$ - $\mathrm{Lg}$ nanoparticle dispersions were mixed with equal volume of various dissociating buffers: (i) $10 \mathrm{M}$ urea; (ii) $0.1 \mathrm{M}$ Mercaptoethanol; (iii) $1 \%$ (w/v) SDS; (v) 0.1 M DTT. Dispersions were incubated for 60 min with each buffer and then particle size was measured following the method described in section 2.2.3.

\subsubsection{Zeta potential}

Zeta potential of nanoparticle samples was measured by Dynamic light scattering technique using Zetasizer Nano Z in Electrophoretic Light Scattering mode (Malvern Instruments Inc., Malvern, United Kingdom) at $25 \pm 0.1{ }^{\circ} \mathrm{C}$ and five measurements were taken for each sample. A folded capillary cell (DTS1070) was used to measure the zeta potential. The cell was washed by ethanol and deionised water before each measurement.

\subsubsection{Caffeine determination by HPLC}

An isocratic Reversed phase High Performance Liquid Chromatography (RP-HPLC) equipped with Gilson Model 302 Pump, CE212 Variable wavelength ultraviolet detector and Hewlett Packard 3396A integrator was used to quantify the caffeine concentration contained in permeate. The column used was Ace $5 \mathrm{C} 18,25 \mathrm{~cm} \times 4.6 \mathrm{~mm}$ 
219 (Hinchhrom Limited, United Kingdom, particle size $5 \mu \mathrm{m}$ ), operated at $25 \pm 1^{\circ} \mathrm{C}$, the 220 flow rate was $1.0 \mathrm{~mL} / \mathrm{min}$, with $50 \mu \mathrm{L}$ injection volume, while mobile phase comprised 221 of methanol/water (50/50). Absorption wavelength was selected at $273 \mathrm{~nm}$, which is 222 the maximum wavelength for caffeine. Standard solutions of caffeine were prepared in 223 deionized water in a range of concentrations from $0.001 \%$ to $0.01 \%(\mathrm{w} / \mathrm{v})$. A standard 224 calibration plot was prepared by plotting concentration versus area from which the concentration of caffeine was determined in a range of samples.

\subsubsection{Encapsulation efficiency}

To study the encapsulation efficiency of caffeine into $\beta$-Lg nanoparticles, the caffeine encapsulated by the $\beta$-Lg particles was separated from free caffeine by centrifugal ultrafiltration membranes of 50KDa MWCO, Vivaspin ® 20 (Sartorius Stedim Biotech, Germany). To quantify the amount of free and entrapped caffeine, $5 \mathrm{ml}$ of protein and caffeine solution prepared according to section 2.2.2 was sampled and centrifuged for $30 \mathrm{~min}$ at $2000 \mathrm{rpm}$. The retentate was removed carefully by pipette for further analysis while the permeate was used for determination of free caffeine using RP-HPLC. The amount of the entrapped caffeine was determined based on the determination of free caffeine in the permeate and by applying a mass balance. The entrapment efficiency of caffeine was calculated based on the following equation:

Entrapment efficiency $(\%)=\frac{\text { mass of caffeine entrapped }}{\text { original mass of caffeine }} \times 100$

\subsubsection{In-vitro gastrointestinal digestion}

Gastric digestion. The in-vitro gastric model protocol was adapted from Zeece et al. (2008) and Sarkar et al. (2009) with some modifications introduced here. Simulated gastric fluid (SGF) containing $2 \mathrm{~g}$ of $\mathrm{NaCl}$ and $7 \mathrm{~mL}$ of $\mathrm{HCl}$, without the addition of 
pepsin was diluted to $1 \mathrm{~L}$ and $\mathrm{pH}$ adjusted to 1.2 using 1.0M HCl. Afterwards, 14.93 mg of pepsin enzyme was added to $7 \mathrm{ml}$ of SGF and held at $37^{\circ} \mathrm{C}$ with continuous shaking at $95 \mathrm{rpm}$ in a temperature-controlled water bath (Grant OLS 200, Grant Instrument, United Kingdom) to mimic the conditions in the stomach. The $\mathrm{pH}$ and temperature were continuously monitored and controlled.

Caffeine-loaded $\beta$-Lg nanoparticles and pure $\beta$ - $L g$ nanoparticles separated from $14 \mathrm{~mL}$ suspensions by ultrafiltration (UF) (as described in section 2.2.11) were re-dispersed in $14 \mathrm{~mL}$ of SGF. Then $7 \mathrm{~mL}$ of SGF containing pepsin was added to the mixture to make up a final volume of $21 \mathrm{~mL}$ (protein: enzyme ratio 1.87:1 w/w). The mixture was incubated at $37^{\circ} \mathrm{C}$ for up to $2 \mathrm{~h}$ and samples were withdrawn at different time intervals for particle size measurement and RP-HPLC analysis. The $\mathrm{pH}$ of the mixture was maintained at 1.5 using $1 \mathrm{M} \mathrm{HCl}$. The digestion reaction was terminated by raising the $\mathrm{pH}$ to 8 with $0.1 \mathrm{M} \mathrm{NaOH}$ prior to any analysis.

Gastrointestinal digestion. This method was based on a digestion protocol according to Mills et al (2008) and Maccaferri et al (2012) with some modifications. A $15 \mathrm{ml}$ dispersion sample containing nanoparticles with and without caffeine was adjusted to pH 2 by using $\mathrm{HCl}(6 \mathrm{M})$ and mixed with $2.5 \mathrm{ml} 0.1 \mathrm{M} \mathrm{HCl}$ which contained $0.27 \mathrm{~g}$ pepsin (protein: pepsin ratio 1:9 w/w). The solution was incubated in the $37{ }^{\circ} \mathrm{C}$ water bath with a shaker at $95 \mathrm{rpm}$ for two hours. A $0.1 \mathrm{ml}$ sample was taken for analysis of released caffeine by HPLC. Then the rest of the sample was mixed with $12.5 \mathrm{ml}$ $\mathrm{NaHCO}_{3}$ in which 56mg pancreatin (protein: pancreatin ratio 1.07:2 w/w) (P3292, Sigma; 4UPS) and 0.35g bile (protein: bile ratio 1:11.7 w/w) (B 8631, Sigma) were dissolved and the $\mathrm{pH}$ of the sample was adjusted to 7 using $\mathrm{NaOH}(6 \mathrm{M})$. Samples were incubated for three hours. After small intestinal phase incubation samples were filtered through a $0.45 \mu \mathrm{m}$ filtration unit and analysed by HPLC to determine the caffeine released. 


\subsubsection{Caffeine adsorption isotherm}

To describe the caffeine adsorption process to $\beta$ - $\mathrm{Lg}$ nanoparticles and native protein the experimental data were fitted to Langmuir adsorption model:

(1) $C a d=\operatorname{Cad}_{\max } \cdot k \cdot C /(1+k \cdot C)$

where, $C a d$ is the caffeine adsorbed to $\beta-\mathrm{Lg}$ per protein at equilibrium $\left(\mathrm{mg} \mathrm{mg}^{-1}\right.$ protein), $C a d \max _{\max } k$ is the maximum amount of caffeine absorbed to $\beta-\mathrm{Lg}\left(\mathrm{mg} \mathrm{mg}^{-1}\right.$ protein), $C$ the concentration of caffeine free in solution at equilibrium $\left(\mathrm{mg} \mathrm{ml}^{-1}\right)$ and $k$ the adsorption constant $\left(\mathrm{ml} \mathrm{mg}^{-1}\right)$.

\subsubsection{Calculations and Statistical Analysis}

Calculation of the net charge of $\beta$ - $\mathrm{Lg}$ at different values of $\mathrm{pH}$ was performed with the online "protein calculator v3.4" software (http://protcalc.sourceforge.net) using the sequence of $\beta-\mathrm{Lg}$. The results were statistically analysed by analysis of variance using IBM $^{\circledR}$ SPSS $^{\circledR}$ Statistics version 20.0. Means and standard deviations from at least three measurements carried out on two freshly prepared $\beta-\mathrm{Lg}$ nanoparticles were repeated. The significance level was set at 0.05 . Data fitting of experimental data to models was performed with Solverfrom Excel MS Office 2013 (Microsoft Corporation, Redmond, WA, USA).

\section{Results and Discussion}

\subsection{Effect of $\mathrm{pH}$, temperature and heat time on $\beta$-Lg nanoparticles}

Native and heated $\beta$-Lactoglobulin $(\beta$-Lg) solutions were prepared $0.2 \%(\mathrm{w} / \mathrm{v})$ and $\mathrm{pH}$ adjusted near to their isoelectric point ( $\mathrm{pH}$ 6.0). All samples appeared to be transparent initially. Also there was only slight turbidity after $\mathrm{pH}$ adjustment in agreement with observations previously reported (Chanasattru, Jones, Decker, \& McClements, 2009; Mehalebi, Nicolai, \& Durand, 2008; Nicolai et al., 2011; Zimet \& Livney, 2009). High 
309

turbidity after heating at $75^{\circ} \mathrm{C}$ for 45 minutes appeared to provide a rough quantitative indication of protein aggregation in the system. A monodisperse particle size distribution was obtained consistently with particles of an average diameter about 200 nm to $300 \mathrm{~nm}$. (See Fig. 1).

$\begin{array}{rllll} & & \text { Size (d.nm): } & \text { \% Intensity: } & \text { St Dev (d.nm): } \\ \text { Z-Average (d.nm): } 310.3 & \text { Peak 1: } & 356.7 & 100.0 & 149.1 \\ \text { Pdl: } 0.194 & \text { Peak 2: } & 0.000 & 0.0 & 0.000 \\ \text { Intercept: } 0.980 & \text { Peak 3: } & 0.000 & 0.0 & 0.000 \\ \text { Result quality: } & & & \end{array}$

Size Distribution by Intensity

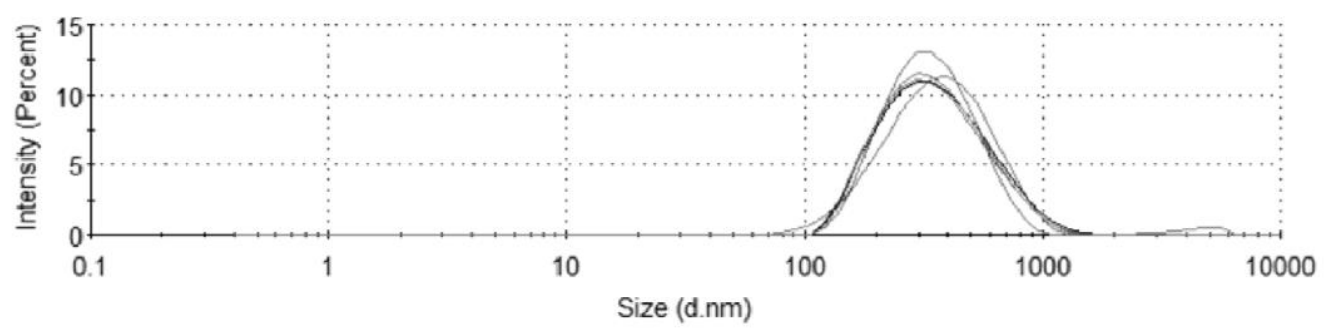

Figure 1. The example of particle size result by DLS for nanoparticls produced at pH 6 and heating at $75^{\circ} \mathrm{C}$ for 45 mins.

\subsubsection{Effect of pH}

Near the isoelectric point (pI) of the protein the overall charge is close to zero therefore, repulsive electrostatic interactions between protein molecules will be minimised and their aggregation will be promoted. In particular, $\beta$-Lg aggregation close to its $\mathrm{pI}$ and under denaturing conditions was reported to produce particulate gels, which were composed of spherical particles (Donald, 2007).

Here we studied the effect of a range of $\mathrm{pH}$ 's near and above the $\mathrm{pI}$ on the particle size. The $\mathrm{pH}$ of the aqueous $\beta-\mathrm{Lg}$ solution $(0.2 \% \mathrm{w} / \mathrm{v})$ before $\mathrm{pH}$ adjustment was $6.8 \pm 0.3$. At this $\mathrm{pH}$, a clear solution was obtained even after heating. This $\mathrm{pH}$ was further away from the $\mathrm{pI}$ therefore, strong electrostatic repulsive interactions between protein molecules hindered their self-aggregation which resulted in reduced turbidity. To test the effect of $\mathrm{pH}$ on protein aggregation and formation of nanoparticles samples were incubated at $\mathrm{pH}$ close to the $\mathrm{pI}$ in the range of 5.7 to 6.2 (see figure 2). At $\mathrm{pH} 5.7$ the 
largest particle size, about 600nm, was recorded and clearly, particle size decreased with an increase in $\mathrm{pH}$. This indicated that when the $\mathrm{pH}$ was close to $\mathrm{pI}$, and the repulsive electrostatic forces between molecules were minimised, large particles could be formed. Conversely, when the $\mathrm{pH}$ was far from the $\mathrm{pI}$, the repulsive electrostatic forces were too strong to promote aggregation and consequently smaller particles were produced. Moreover, according to Tauliera and Chalikian (2001), within pH 5.7-6.2 only a slight change in its tertiary structure occurred but no alteration in secondary structure. Therefore, the hidden hydrophobic parts of $\beta$-Lg were exposed upon $\mathrm{pH}$ adjustment.

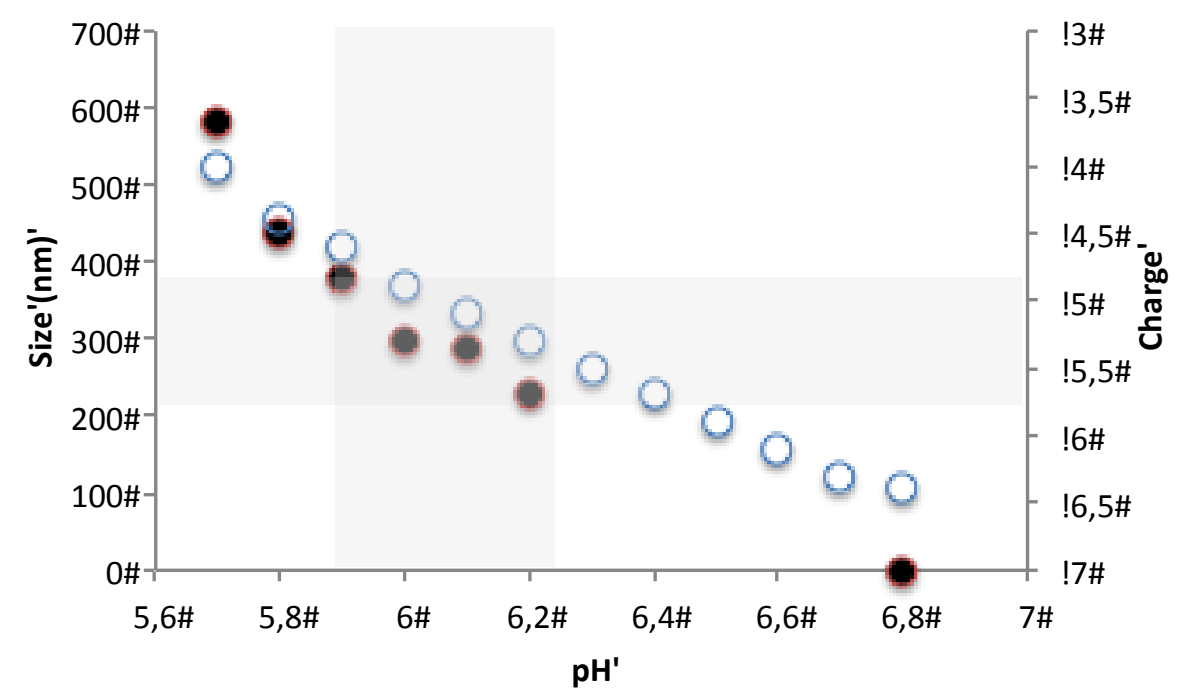

Figure 2. Effect of $p H$ in size and net charge of protein nanoparticles. Size: black circles; protein charge: white circles. Experiments were carried out in duplicate and mean standard deviations were 0.6-9.1 $\mathrm{nm}$

Figure 2 shows the relationship between $\mathrm{pH}$ and particle size and protein's net charge. It was concluded that to form nanoparticles with size in the range of $200 \mathrm{~nm}-350 \mathrm{~nm}$ and colloidal stability the $\mathrm{pH}$ should be strictly controlled at 5.9 to 6.2 and protein's net charge between -5.8 to -4.8 . Small changes in $\mathrm{pH}$ outside this range leads to small 
changes in the protein charge but dramatic changes in particle size. So these results highlight the effect of a narrow range of $\mathrm{pH}$ close to the protein's $\mathrm{pI}$ on particle size.

\subsubsection{Effect of temperature}

The heating temperature was also found to have a significant effect on particle size at constant protein concentration. The turbidity of $\beta-\mathrm{Lg}$ solution heated at $50-60^{\circ} \mathrm{C}$ remained relatively low but increased steeply from $60-75^{\circ} \mathrm{C}$. Reproducible size measurements were difficult to obtain at $65^{\circ} \mathrm{C}$ and a bimodal distribution was obtained. For instance, the peak of the first distribution produced with $0.2 \%(\mathrm{w} / \mathrm{v}) \beta-\mathrm{Lg}$ was recorded at $3.81 \mathrm{~nm}$, and the sub-population was found at $145 \mathrm{~nm}$. The first population was conjectured to be native $\beta-\mathrm{Lg}$ which is known to have a hydrodynamic radius of around $2.5 \mathrm{~nm}$ (Mehalebi et al., 2008). The possible reason of obtaining such population as explained by Bauer et al. (Bauer, Carrotta, Rischel, \& Ogendal, 2000) is that early aggregation of $\beta-\mathrm{Lg}$ is initiated only at $67.5^{\circ} \mathrm{C}$. Significantly larger nanoparticles were formed at $75^{\circ} \mathrm{C}$ than at $65^{\circ} \mathrm{C}$. This suggests that $65^{\circ} \mathrm{C}$ was not sufficient to induce complete $\beta$-Lg chain unfolding to produce nanoparticles in a consistent manner. On the other hand, at $75^{\circ} \mathrm{C}$, a monodisperse particle size distribution was obtained consistently with particles of an average diameter about $200 \mathrm{~nm}$.

The findings were in agreement with those by Mehalebi et al. (2008) and Gulseren et al. (2012), who found that elevated temperature could accelerate the rate of aggregation to produce larger nanoparticles. Overall the particle sizes reported here are in agreement with those reported by Donato, Schmitt, Bovetto, and Rouvet (2009), who had observed elongated compact aggregates smaller than $200 \mathrm{~nm}$ upon heating of $1 \%(\mathrm{w} / \mathrm{v}) \beta-\mathrm{Lg}(\mathrm{pH}$ 5.9) at $75^{\circ} \mathrm{C}$. Also Jones et al. (2010) had produced $\beta$-Lg particles $(\mathrm{d}<300 \mathrm{~nm})$ with good stability to sedimentation as in this study under similar conditions. H.J. Giroux and Britten (2011) reported whey protein nanoparticles in the range of $194 \mathrm{~nm}$ produced at $\mathrm{pH} 5.0$ using pH-cycling treatment. According to Jones et al. (2010) optimal conditions for production of $\beta$ - $\mathrm{Lg}$ nanoparticles occurred when the system was heated 

above thermal denaturation temperature of $\beta-\mathrm{Lg}$ and at a $\mathrm{pH}$ close to its $\mathrm{pI}$ which is in agreement with the above findings; these nanoparticles were reported to be irreversible protein aggregates and generally stable towards storage and $\mathrm{pH}$ changes.

\subsubsection{Heating time}

Besides temperature, the heating time is another factor which has a significant effect on the particle size. Previous studies suggested that long heating time promotes the formation of large aggregates. This was confirmed in the experiments carried out at varying heating times ( 15 to 75 minutes) but constant temperature, $75{ }^{\circ} \mathrm{C}$ (Figure 3); Note that although the water bath was at $75{ }^{\circ} \mathrm{C}$ it took about $12-14$ mins for the temperature in the dispersion to reach $75^{\circ} \mathrm{C}$.

Particle size increased from $218 \mathrm{~nm}$ to $327 \mathrm{~nm}$ in the studied heating time range. The conformation structure changes might happen including the hidden hydrophobic groups at the central cavity and disulphate bonds exposing to the environment and the particles were produced. The polydispersion index (PDI) decreased and had a minimum at 45mins. As shown by the low PDI number at this heating time a monodispersion was obtained.

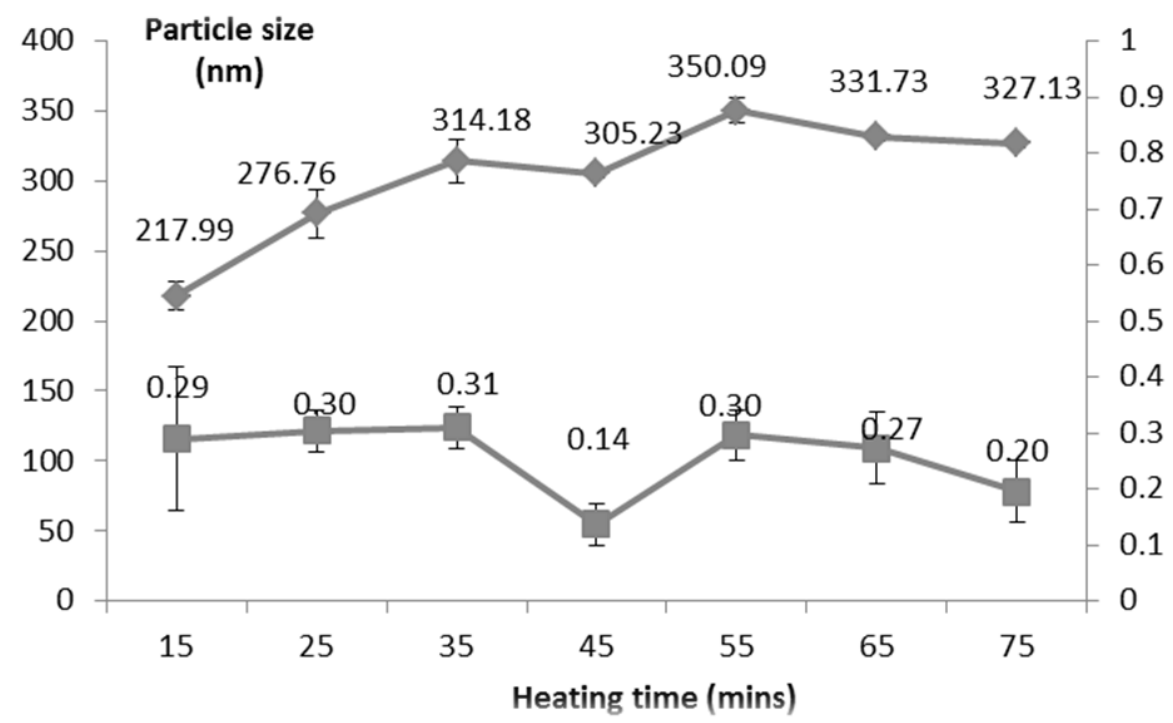

Fig.3: $\beta$-Lg nanoparticle size for continuing heating (15minutes-75mintues). $\triangleleft$ The $\beta$ - 
392

393

394

395

396

397

398

399

400

401

402

403

404

405

406

407

408

409

410

411

412

413

414

415

416

417

418

419

In summary, both heating load (combination of temperature and time) and $\mathrm{pH}$ were found to be the key operating parameters at constant protein concentration in the production of nanoparticles of a given size. The $\beta$ - $\mathrm{Lg}$ nanoparticles in the range of 200$300 \mathrm{~nm}$ were obtained in a consistent and reproducible manner by inducing heat denaturation and aggregation of the protein in an aqueous solution at $0.2 \%, \mathrm{pH} 6.0$ and $75{ }^{\circ} \mathrm{C}$ for 45 minutes. At these conditions, a monodisperse size distribution was obtained and with good reproducibility.

Protein aggregation may occur due to covalent and non-covalent interactions between unfolded protein molecules. As protein denatures it will unfold to expose the hydrophobic groups as well as the reactive thiol group at $\mathrm{Cys}^{121}$ which leads to protein molecules interacting via non-covalent interactions (hydrophobic interaction, hydrogen bonding) and covalent interactions (disulphide bonds) to form particles of a given microstructure.(Donato et al., 2009; Havea, Singh, \& L.K., 2001). In order to obtain an insight into the physical characteristics of the nanoparticles and their microstructure, the following characterisation study was carried out.

\subsection{Characterisation of $\beta-\mathrm{Lg}$ nanoparticles}

\subsubsection{Stability to dissociating buffers}

In order to get an insight into the type of the microstructure formed and the main interactions governing its formation the stability of the particles to several buffers was investigated. All samples were filtered by $0.45 \mu \mathrm{m}$ filter before the incubation with dissociation buffers. The effect of dissociating buffers was determined based on changes in particle size (Table 1). 
Table 1: Effect of dissociating buffers on nanoparticle diameter (nm). The incubation time with dissociating buffers was 60 minutes.

\begin{tabular}{cccccc}
\hline Before & 10M & $1 \%(W / V)$ & $0.1 M$ & 0.1 M DTT \\
& incubation & Urea & SDS & 2-Mercaptoethanol & \\
\hline Particle size & $173.0 \pm 12.5^{a}$ & $234.2 \pm 1.9^{b}$ & $17.41 \pm 8.8^{c}$ & $176.5 \pm 0.9^{a}$ & $186.1 \pm 1.5^{a}$ \\
\hline
\end{tabular}

Experiments were carried out in duplicate, mean values with different superscript letters are significantly different at $\mathrm{p}<0.05$, the particle size before incubation is lower than $200 \mathrm{~nm}$ due to the filtration of $0.45 \mu \mathrm{m}$ filter.

Sodium dodecyl sulphate (SDS) interacts with proteins via electrostatic interactions and hydrophobic interactions while keeping covalent bonds intact.(Reynolds \& Tanford, 1970; Roy, Kumar, \& Gurusubramanian, 2012). A significant reduction in particle size was observed which demonstrates that hydrophobic interactions are essential to the stabilisation of the microstructure of these particles.

Urea is a very powerful protein denaturant with the ability to break hydrogen bonds. It is considered that urea acts by breaking down protein hydrogen bonds as it interacts with peptide groups in unfolded proteins by hydrogen bonding. Interestingly, most $\beta$ Lg nanoparticles were not disrupted by urea. On the contrary, the particle size increased significantly as demonstrated. The swelling of the nanoparticles could be due to the formation of hydrogen bonds with the water molecules within the particles (Huppertz $\&$ de Kruif, 2008). These results demonstrated the presence of hydrogen bonds within the internal structure of $\beta-\operatorname{Lg}$ nanoparticles.

2-Mercaptoethanol was added to $\beta$ - $\mathrm{Lg}$ nanoparticle dispersions to cleave disulphide bonds. Interestingly 2-Mercaptoethanol had no significant effect on the size of the nanoparticles, therefore, disulphide bonds were not responsible for the microstructure formation. In order to confirm the above results, another dissociating buffer $0.1 \mathrm{M}$ Dithiothreitol (DTT) was used. DTT is a dissociating buffer, which disrupts disulphide 
bonds. The nanoparticles were stable during incubation with DTT for 60mins and even after one day (data not shown here). These results confirmed that disulphide bonds were not mainly responsible for the microstructure formation.. Various authors (Alting, Hamer, de Kruif, Paques, \& Visschers, 2003; H. J. Giroux et al., 2010; Ko \& Gunasekaran, 2006; Mudgal, Daubert, \& Foegeding, 2011; Nicolai et al., 2011) have demonstrated the significant role of thiol-disulphide reactions in $\beta$-Lg aggregation but the reaction was shown to be favoured at neutral to alkaline pHs. In addition Alting et al. (Alting et al., 2003) had further ascertained the fact that disulphide bonds did not significantly contribute to the acid-induced aggregation of diluted solutions of whey protein in the initial stage of aggregation. However, partially cross-linked disulphide bonds were found in protein gels kept for a period of time, namely ageing period (Alting et al., 2003; H. J. Giroux et al., 2010; Nicolai et al., 2011). Alting et al. (2003) demonstrated that the formation of disulphide crosslinking was strongly affected by the $\mathrm{pH}$ (at pH 5 only 1:3160 sulphur groups is deprotonated and able to initiate thiol/disulphide exchange reactions) and protein concentration (4.5\% initial protein concentration was identified as the critical value below which no significant crosslinking may occur). Since the $\beta$-Lg nanoparticles produced in this study did not undergo the aforementioned ageing period and the $\mathrm{pH}$ and protein concentrations were not favourable to disulphide crosslinking it is reasonable to conclude that disulphide bonds did not actively participate in the formation of the microstructure of the nanoparticles produced in the current study.

In summary, the predominant interactions responsible for the microstructure of the nanoparticles were found to be hydrogen bonding and hydrophobic interactions. Increased hydrogen bonding induces the formation of $\beta$-sheets in a protein which, is commonly found in aggregates (Gunasekaran et al., 2006). Hydrophobic interactions also played a major role in the aggregation process of $\beta$ - $\mathrm{Lg}$ as expected since this protein has significant portions of hydrophobic patches, with the exact effective hydrophobicity reported to be 12.2 (Gunasekaran et al., 2006; Hansted, Wejse, 
Bertelsen, \& Otzen, 2011; Ko \& Gunasekaran, 2006) and upon denaturation this area 476 will be further exposed.

477

478

479

480 481

\subsubsection{Microscope image of nanoparticle}

To further characterise the microstructure of $\beta$ - $\mathrm{Lg}$ nanoparticles environmental scanning electron microscopy was carried out on samples produced at the optimum conditions (described in 2.2.5).

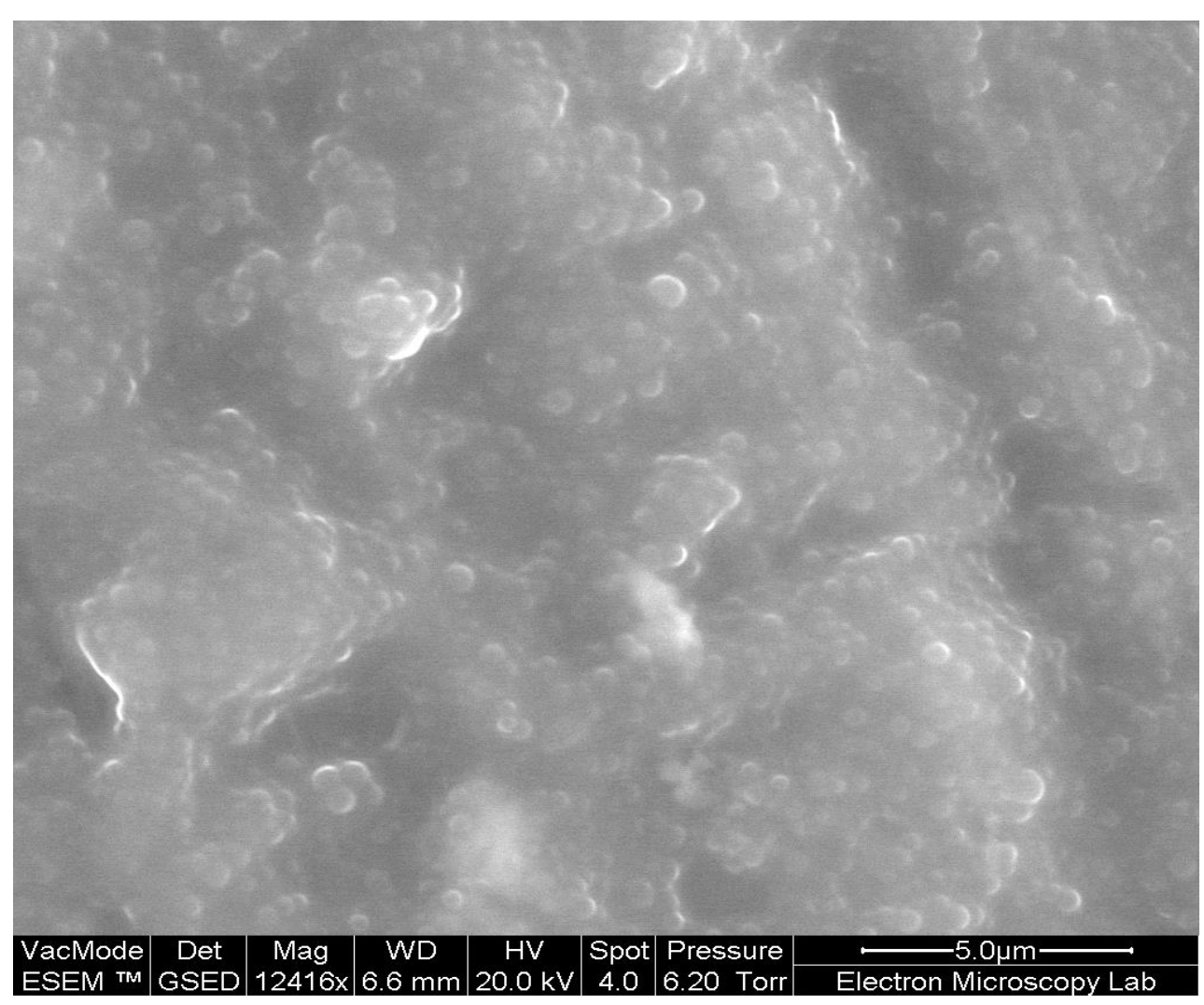

Figure 4: the ESEM image of $\beta$-Lg nanoparticles

The ESEM image in Figure 4 shows spherical aggregates and in the range of sizes of those measured by DLS. This is in agreement with Krebs et al (Krebs, Devlin, \& Donald, 2009) who reported the formation of spherical aggregates at the $\mathrm{pH}$ close to protein's $\mathrm{pI}$. 
Moreover, the zeta potential of these nanoparticles was determined as the key indicator of the stability of colloidal dispersions. The zeta potential of the $\beta$ - $\mathrm{Lg}$ dispersion was $37.42 \pm 2.93 \mathrm{mV}$ which indicated a moderate stable colloidal system.

\subsubsection{Yield of aggregation of $\beta-\mathrm{Lg}$}

In preliminary filtration experiments with an aqueous solution of $\beta-\mathrm{Lg}$ and a $50 \mathrm{KDa}$ ultrafiltration membrane, it was shown that any non-aggregated $\beta$-Lg permeated through the ultrafiltration membrane and thus the aggregation yield was determined based on the determination of protein concentration in the permeate by using bicinchoninic acid (BCA) method as described in 2.2.4. Nearly 93\% of $\beta$-Lg aggregated when heated at $75^{\circ} \mathrm{C}$ for $45 \mathrm{~min}$. These aggregation yields were similar to those reported by others at higher heating loads (Donato et al., 2009; H. J. Giroux et al., 2010; Moitzi et al., 2011; Mudgal et al., 2011; Schokker, Singh, Pinder, \& Creamer, 2000); Giroux et al. (H. J. Giroux et al., 2010) reported an aggregation yield of $97.3 \%$ after heating $1 \%(\mathrm{w} / \mathrm{v})$ whey protein dispersion at $80^{\circ} \mathrm{C}$ for $15 \mathrm{~min}$.

\subsection{4 $\beta$-lactoglobulin conformational changes by fluorescence spectroscopy}

The $\beta$-Lg contains two tryptophan residues, $\operatorname{Trp}^{19}$ and $\operatorname{Trp}^{61}: \operatorname{Trp}^{19}$ within the cavity of $\beta$-Lg whereas $\operatorname{Trp}^{61}$ is located at the surface of the protein molecule and is close to the Cys $^{66}{ }_{-C y s}{ }^{160}$ disulfide bridge (Qin, Bewley, et al., 1998; Qin, Creamer, Baker, \& Jameson, 1998). The X-ray crystallographic image also illustrated that $\operatorname{Trp}^{19}$ is located in the interior of the $\beta$-Lg molecule, which is the major binding point of $\beta$ - $\operatorname{Lg}$ (Sawyer et al., 1985). A mutant $\beta$ - $\operatorname{Lg}$ molecule study helped to prove that $\operatorname{Trp}^{19}$ was a major fluorophore of $\beta-\mathrm{Lg}$ in the non-polar environment (Creamer, 1995). By the influence of heat, the conformation changed at about $50{ }^{\circ} \mathrm{C}$, one of the tryptophans was transferred to a more polar environment accessible to solvent and above $70^{\circ} \mathrm{C}$ the second tryptophan residue became exposed to solvent. But even at $90^{\circ} \mathrm{C}$, the second one was partially buried (Mills, 1976). Therefore in order to investigate conformational changes in $\beta-\mathrm{Lg}$ after heat denaturation and after caffeine encapsulation the 
518 fluorescence emission spectra of tryptophan was measured (Fig. 5). An increase in the

519 fluorescence intensity was observed for $\beta$ - $\mathrm{Lg}$ nanoparticles and a fluorescence 520 quenching effect by the caffeine upon binding to the nanoparticles. The increase in 521 fluorescence intensity can be explained based on the exposure of previously buried Trp 522 groups upon heating induced conformational changes in the protein.

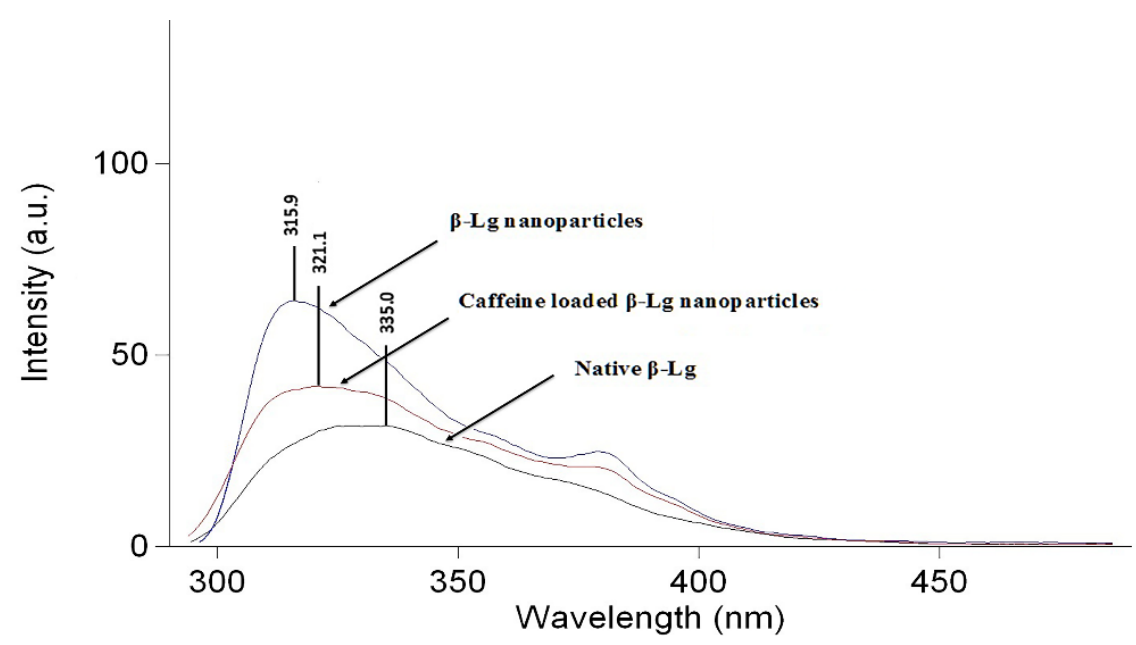

Figure 5: the fluorescence emission changes of native $\beta$ - $L g, \beta$-Lg nanoparticles and caffeine loaded $\beta$-Lg nanoparticles.

\subsubsection{Mechanism of nanoparticle formation}

Based on previous studies on $\beta$ - $\mathrm{Lg}$ and our observations above the following mechanism of nanoparticle formation is proposed. At neutral $\mathrm{pH}, \beta-\mathrm{Lg}$ exists as dimer in aqueous solution. Upon $\mathrm{pH}$ adjustment (to $\mathrm{pH}$ 6) and heating the dimer dissociates and denatures to reactive monomers. Protein molecules start to unfold and hydrophobic groups are exposed (as shown by fluorescence measurements) which promote intermolecular non-covalent interactions (hydrophobic interactions, and hydrogen bonding) to form particles of a given microstructure as demonstrated by the stability to buffers. Although at these denaturing conditions the reactive thiol group in the protein 
would get exposed the $\mathrm{pH}$ and protein concentration conditions (and lack of aging time) used in this study did not lead to the formation of disulphide bonds and subsequent cross-linked gel-like structure. Moreover, the spherical aggregates (as visualised by ESEM) had a good colloidal stability which was supported by an overall strong negative charge $(-37.42 \pm 2.93 \mathrm{mV})$ measured as zeta-potential.

\subsection{Yield of caffeine encapsulation}

The yield of caffeine encapsulation increased when caffeine to $\beta-\mathrm{Lg}$ molar ratio increased reaching a maximum $13.54 \%$ at a molar ratio of 50 (mass ratio caffeine to $\beta$ $\operatorname{Lg} 1: 2)$ (Table 2). Above this maximum, a slow reduction of the percentage of caffeine encapsulation was observed for higher caffeine to $\beta$-Lg molar ratio values. In addition, caffeine-loaded particles were significantly larger than those without caffeine (over 350 nm). Li et al. (Li, Du, Jin, \& Du, 2012) and Shpingelman et al. (Shpigelman, Cohen, \& Livney, 2012) had also found a similar trend for their EGCG (epigallocathechin-3-gallate)-loaded $\beta$-Lg nanoparticles.

Table 2: Caffeine encapsulation. All the encapsulation efficiency results are the average of three replicates.

\begin{tabular}{|c|c|c|c|c|c|}
\hline $\begin{array}{l}\text { Caffeine to } \beta-L g \\
\text { ratio }\end{array}$ & 10:1 & $20: 1$ & $50: 1$ & 100: & 200:1 \\
\hline $\begin{array}{l}\text { Encapsulation } \\
\text { efficiency (\%) }\end{array}$ & $10.25 \pm 1.2^{b}$ & $11.68 \pm 3.0^{a}$ & $13.54 \pm 3.3^{a}$ & $10.07 \pm 2.0^{c}$ & $9.73 \pm 0.2^{d}$ \\
\hline Particle size & $374.1 \pm 5.1^{a}$ & $366.5 \pm 4.7^{b}$ & $381.7 \pm 1.7^{c}$ & $359.6 \pm 3.0^{d}$ & $356.0 \pm 2.6^{d}$ \\
\hline
\end{tabular}

Experiments were carried out in triplicate, mean values with different superscript letters are significantly different at $\mathrm{p}<0.05$ 
558 The same results were plotted as an adsorption isotherm (Figure 6) as it was 559 hypothesised that caffeine bound (adsorbed) the exterior of the nanoparticles up to

Table 3: Adjustment of caffeine adsorption to Langmuir model

\begin{tabular}{ccc} 
& Native $\beta$ - Lg & $\beta$-Lg nanoparticles \\
Cad max & 0,103 & 0,263 \\
$k$ & 1,194 & 0,423 \\
$r 2$ & 0,96332 & 0,96244 \\
\hline
\end{tabular}
reaching equilibrium concentration. Interestingly it was found that the equilibrium concentrations of caffeine bound (measured as caffeine mass per protein mass) and caffeine free in solution followed a Langmuir type isotherm. Parameters of adjustment of experimental data to Langmuir model are shown in Table 3.
566

567 In the case of nanoparticles, a maximum binding capacity of $0.205 \mathrm{mg}$ caffeine per $\mathrm{mg}$

$568 \beta$-Lg was found which means 19.4 molecules of caffeine per protein. However, when 569

570

571

572

573

574

575

the same experiments were conducted with native $\beta-\operatorname{Lg}$ the maximum binding capacity was only $0.084 \mathrm{mg}$ caffeine per mg protein. Additionally, caffeine had three times more affinity for partially denatured $\beta$-Lg in nanoparticles than for native protein.

This clearly shows that the conformational change induced in the protein due to heat denaturation led to an increase in binding capacity. 


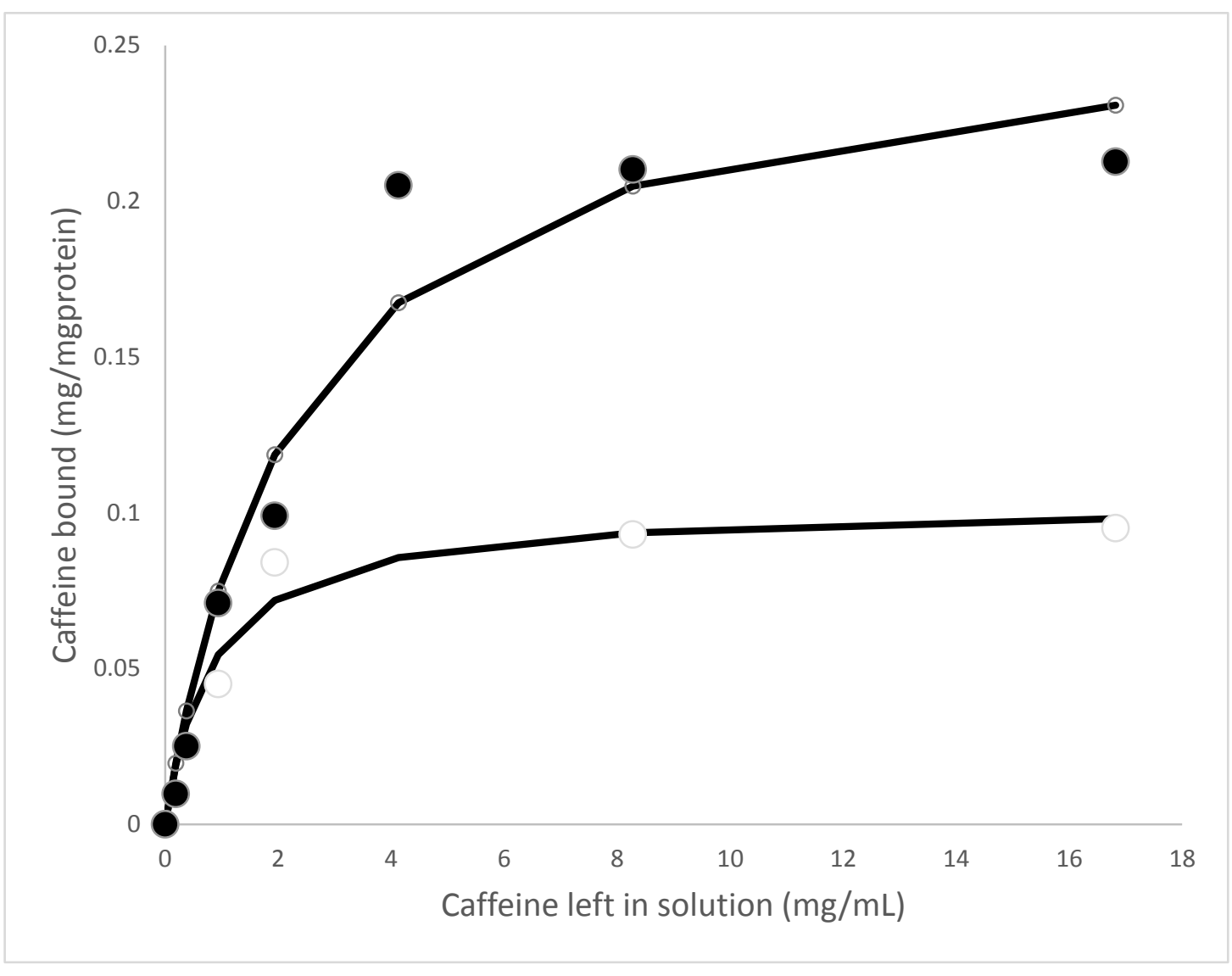

Figure 6: Isotherm of caffeine encapsulation of native $\beta$ - Lg (white circles) and the $\beta$ -

Lg nanoparticles (black circles). Lines represent adjustment to Langmuir model.

\subsection{Simulated gastric digestion}

The in-vitro experiment was carried out by suspending the nanoparticles containing caffeine in simulated gastric fluid (SGF) with pepsin for 120 min under continuous shaking at $37^{\circ} \mathrm{C}$. Conditions of temperature and $\mathrm{pH}$ were set equivalent to the normal gastric digestion conditions (Shpigelman et al., 2012). The protein: enzyme ratio (1.875:1) used here was similar ratio to that reported in other works (Chen \& Subirade, 2005; Sarkar, Goh, Singh, \& Singh, 2009; Shpigelman et al., 2012; Zeese, Huppertz, \& Kelly, 2008). It is important to note that optimal ratio that suits the exact physiological secretion in humans was extremely hard to establish due to the variation in gastric secretions in different individual's health conditions and food choice (Sarkar et al., 2009). Various protein: enzyme ratio had been proposed by Kitabatake \& Kinekawa (Kibatake \& Kinekawa, 1998), Zeece et al. (Zeese et al., 2008); Sarkar et al. (Sarkar et 
593

594

595

596

597

598

599

600

601

602

603

604

605

606

607

608

609

610

al., 2009), and Shpingelman et al. (Shpigelman et al., 2012) but all the authors claimed that complete hydrolysis of $\beta$-Lg was not achievable at any given pepsin concentration. Therefore, this ratio was chosen here to expose $\beta$ - $\mathrm{Lg}$ nanoparticles to more extreme gastric conditions.

Upon addition to SGF, the $\mathrm{pH}$ of the $\beta$-Lg dispersions dropped immediately to around $\sim 1.5$ to mimic the empty stomach $\mathrm{pH}$ and to provide the optimum conditions for hydrolysis by pepsin. Rapid decay of particle size was observed (Figure 7) and during the incubation period polydispersity increased which can be a consequence of the unspecific action of pepsin on the peptide bonds.

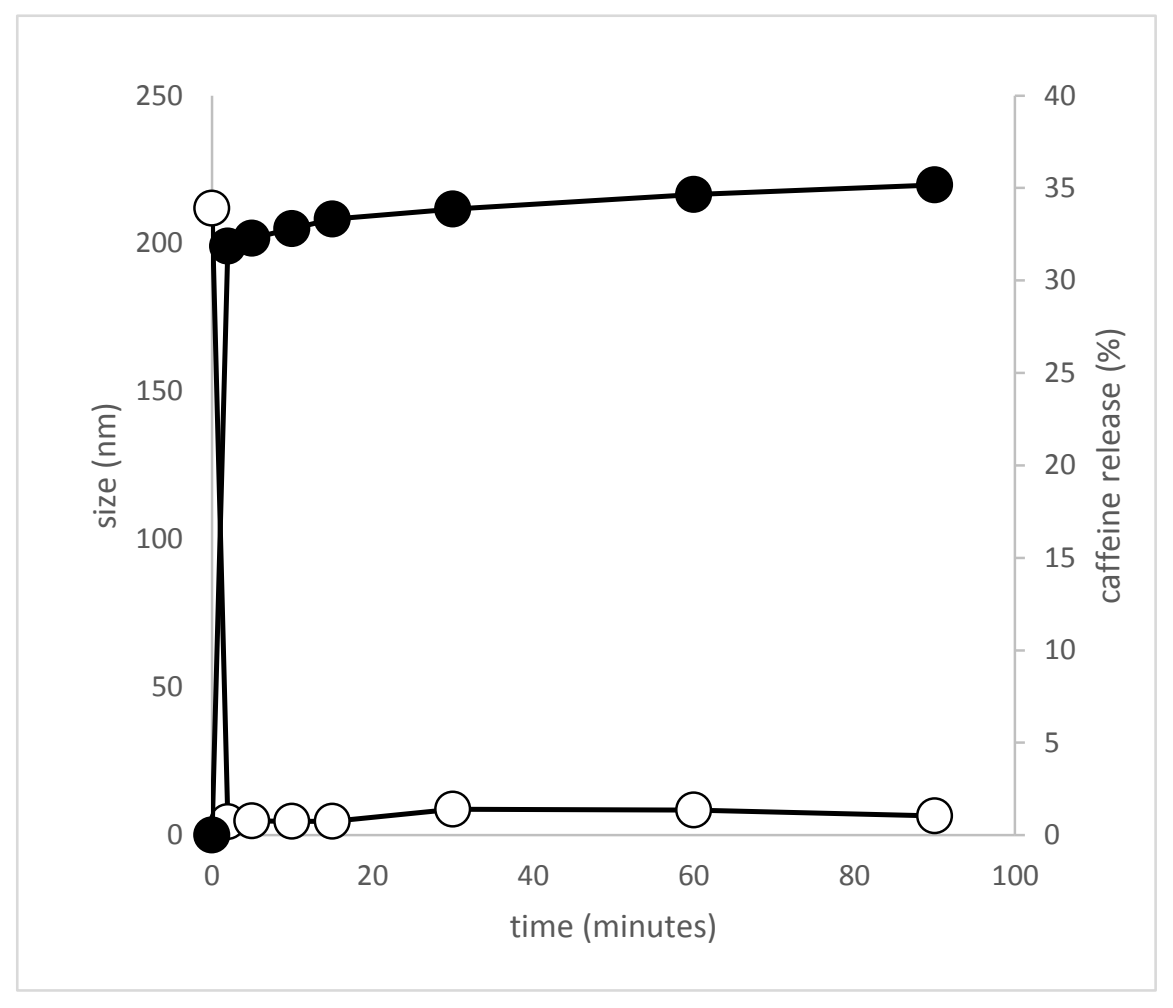

Figure 7. Black circles: Caffeine release percentage under SGF condition (all results are done in duplication.). White circles: Stability of $\beta$-Lg nanoparticles at simulating stomach conditions. Each of these experiments did in duplicate with standard deviations 2.21-3.19\% for release and for size 0.80-2.33 nm

So particle degradation happened in the first 2 minutes. At this time particle size reduced to $5 \mathrm{~nm}$ which corresponds to the average size of a protein dimer (Nicolai et 
al., 2011; Sakurai , Oobatake , \& Goto, 2001) and the size remained as less than 10nm with no significant difference for 60 minutes (Figure 7).

High Burst effect was observed in the kinetic of caffeine release revealing a common problem in the development of controlled release formulations when low molecular weight compounds are loaded in nanoparticles. This Burst effect seems related with the rapid nanoparticle degradation. In spite of this, high amounts of caffeine were retained in the nanoparticle (68.14\% at 2 minutes) and slow and little release of entrapped caffeine was noted, even at the end of incubation (36.4\%). Moreover, the gastric digestion applied in the gastrointestinal digestion experiments where lower protein to pepsin ratio was used (1:9) than in the gastric digestion experiments (1.87:1) (see Methods), led to similar results, $36.71 \%$ caffeine released. Furthermore, almost all the caffeine was released after the small intestinal digestion phase (99.22\%). Our results agreed with those of Shpigelman et al. (2012) as their $\beta$-Lg-EGCG complex managed to preserve $79 \%$ of their contents after $180 \mathrm{~min}$ of incubation in 1:20 pepsin: protein ratio solution

The fact that most of the caffeine is still bound to the protein after the microstructure has been destroyed indicates that the binding of the caffeine to protein is not so dependent on the microstructure but on the protein conformation and the establishment of interactions (most probably hydrophobic and hydrogen bonds) between the protein molecule and the caffeine.

\section{Conclusions}

One of the main outcomes of this study is that we have developed a simple method that relies in the heat denaturation of $\beta-\mathrm{Lg}$ and leads to the consistent production of nanoparticles of given size (average diameter 200-300) and characteristics with colloidal stability and high yield of aggregation $(>93 \%)$ at the optimum conditions of $\mathrm{pH}$ (6) and heat load (heating at $75 \mathrm{C}$ for 45 mins) which, were found to be the key operating parameters. The characterisation of the nanoparticles by a range of techniques 
including fluorescence, DLS, and microscopy in combination with the measurement of their stability to buffers led to an improved insight of their formation and their microstructure at the optimum conditions. In summary, heat denaturation led to the protein unfolding, exposure of hydrophobic regions and subsequent formation of protein aggregates by non-covalent intermolecular interactions.

Maximum encapsulation efficiency of caffeine was $13.54 \%$ at $50: 1$ caffeine to $\beta$ Lg molar ratio. Caffeine- $\beta$ - $\operatorname{Lg}$ nanoparticles $(\sim 350 \mathrm{~nm})$ were found significantly larger than pure $\beta$-Lg nanoparticles $(\sim 250 \mathrm{~nm})$. Heating of $\beta$ - $\mathrm{Lg}$ unfolded the non-polar region in the protein and led to an increase in binding of caffeine as compared to native $\beta-\mathrm{Lg}$. Interestingly, the binding of caffeine to protein followed a Langmuir type isotherm. Both pure $\beta-\mathrm{Lg}$ and caffeine loaded $\beta-\mathrm{Lg}$ nanoparticles exhibited rapid peptic degradation but only $36.4 \%$ caffeine was released under these conditions and complete release at intestinal conditions, hence suggesting improved enteric delivery. Furthermore, both the fitting of the experimental results to a binding isotherm and the low release of caffeine even when complete disruption of the microstructure occurred suggest that caffeine binds to the unfolded protein molecule at a maximum ratio of 19 molecules of caffeine per molecule of protein. Overall the 'encapsulation' efficiency was slightly better than that obtained with liposomes nanoparticles ( $3.8 \%$ to $9.7 \%$ ) produced by Pham et al. (Pham, Jaafar-Maalej, Charcosset, \& Fessi, 2012) utilising phospholipid and cholesterol and less than that obtained with niosomes particles produced from cholesterol and surfactant $(30.4 \%)$ by Khazaeli et al. (Khazaeli, Pardakhty, \& Shoorabi, 2007) but with significantly larger vesicle sizes (6-22 $\mu \mathrm{m})$. Spontaneous binding of caffeine to $\beta$ - $\mathrm{Lg}$ nanoparticles could open the opportunity for the application of this milk protein as a molecular nano-vehicle to manufacture products fortified with caffeine without intense bitterness that may interfere with the original product flavour. Other potential applications include the binding of bioactives to improve their solubility and/or bioavailability. 
670

671

672

673

674

675

676

677

678

679

680

681

682

683

684

685

686

687

688

689

690

691

692

693

694

695

696

697

698

\section{Acknowledgements}

Special thanks to Thong Thong Choo who initiated part of this work as an MSc project which formed the basis of the current project.

\section{Conflict of interest statement}

The author declares that there are no conflicts of interest.

\section{References}

Afferstsholt, T., \& Palmer, S. (2009). Whey proteins: continued market growth despite economic crisis. NUTRAfoods, 8, 56-58.

Alting, A. C., Hamer, R. J., de Kruif, C. G., Paques, M., \& Visschers, R. W. (2003). Number of thiol groups rather than the size of aggregates determines the hardness of cold set whey protein gels. Food Hydrocolloids, 17, 469-479.

Bauer, R., Carrotta, R., Rischel, C., \& Ogendal, L. (2000). Characterisation and isolation of intermediates in b-lactoglobulin heat aggregation. Biophysical Journal, 79, 1030-1038.

C. Baldasso, T.C. Barros, \& Tessaro, I. C. (2011). Concentration and purification of whey proteins by ultrafiltration. Desalination, 278(1-3), 381-386.

Chanasattru, W., Jones, O. G., Decker, E. A., \& McClements, D. J. (2009). Impact of cosolvents on formation and properties of biopolymer nanoparticles formed by heat treatment of $\beta$-lactoglobulin-Pectin complexes. Food Hydrocolloids, 23(8), 2450-2457.

ChemBK. (2017). DL-Dithiothreitol. Retrieved from http://www.chembk.com/en/chem/L-

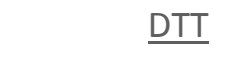

Chen, L., Remondetto, G. E., \& Subirade, M. (2006). Food protein-based materials as nutraceutical delivery systems. Trends in Food Science \& Technology, 17(5), 272-283.

Chen, L., \& Subirade, M. (2005). Chitosan/ $\beta$-lactoglobulin core -shell nanoparticles as nutraceutical carriers. Biomaterials, 26, 6041-6053.

Creamer, L. K. (1995). Effect of sodium dodecyl sulfate and palmitic acid on the equilibrium unfolding of bovine â-lactoglobulin. Biochemistry, 1995(34), 7170-7176.

Donald, A. M. (2007). Why Should Polymer Physicists Study Biopolymers? Journal of Polymer Science: Part B: Polymer Physics, 45, 3257-3262. 
Donato, L., Schmitt, C., Bovetto, L., \& Rouvet, M. (2009). Mechanism of formation of stable heat-induced $\beta$-lactoglobulin microgels. International Dairy Journal, 19, 295-306.

Gilbert, R. M. (1984). Caffeine consumption. Prog Clin Biol Res, 158, 185-213.

Giroux, H. J., \& Britten, M. (2011). Encapsulation of hydrophobic aroma in whey protein nanoparticles. Journal of Microencapsulation (Micro and Nano Carriers), 28(5), 337343.

Giroux, H. J., Houde, J., \& Britten, M. (2010). Preparation of nanoparticles from denatured whey protein by $\mathrm{pH}$-cycling treatment. Food Hydrocolloids, 24, 341-346.

Gulseren, I., Fang, Y., \& Corredig, M. (2012). Whey protein nanoparticles prepared with desolvation with ethanol: characterisation, thermal stability and interfacial behavior. Food Hydrocolloids, 29, 258-264.

Gunasekaran, S., Ko, S., \& Xiao, L. (2006). Use of whey proteins for encapsulation and controlled delivery applications. Journal of Food Engineering, 83, 31-40.

Hansted, J. G., Wejse, P. L., Bertelsen, H., \& Otzen, D. E. (2011). Effect of protein-surfactant interactions on aggregation of $\beta$-lactoglobulin. Biochimica Et Biophysica Acta, 1814, 713-723.

Havea, P., Singh, H., \& L.K., C. (2001). Characterization of heat-induced aggregates of $\beta$ lactoglobulin, $\alpha$-lactalbumin, and bovine serum albumin in a whey protein concentrate environment. Dairy Research, 68(3), 483-497.

Huppertz, T., \& de Kruif, C. G. (2008). Structure and stability of nanogels particles prepared by internal cross-linking of casein micelles. International Dairy Journal, 18, 556-656.

Jauregi, P., \& Welderufael, F. (2010). Added-value protein products from whey extraction, fractionation, separation, purification. NUTRAfoods, 9(4), 13-23.

Jones, O. G., Lesmes, U., Dubin, P., \& McClements, D. J. (2010). Effect of polysaccharide charge on formation and properties of biopolymer nanoparticles created by heat treatment of $\beta$-lactoglobulin-pectin complexes. Food Hydrocolloids, 24, 374-383.

Khazaeli, P., Pardakhty, A., \& Shoorabi, H. (2007). Caffeine-loaded niosomes: characterisation and in vitro release studies. Drug Delivery, 14, 447-452.

Kibatake, N., \& Kinekawa, Y. (1998). Digestibility of bovine milk whey protein and blactoglobulin in vitro and in vivo. J. Agric. Food Chem., 46, 4917-4923. 
Ko, S., \& Gunasekaran, S. (2006). Preparation of sub-100-nm $\beta$-lactoglobulin (BLG) nanoparticles. Journal of Microencapsulation, 23, 887-898.

Krebs, M. R. H., Devlin, G. L., \& Donald, A. M. (2009). Amyloid fibril-like structure underlies the aggregate structure across the $\mathrm{pH}$ range for $\beta$-lactoglobulin. Biophysical Journal, 96, 5013-5019.

Li, B., Du, W., Jin, J., \& Du, Q. (2012). Preservation of (-)-Epigallocatechin-3-gallate Antioxidant Properties Loaded in Heat Treated beta-Lactoglobulin Nanoparticles. Journal of Agricultural and Food Chemistry, 60(13), 3477-3484.

Livney, Y. D. (2010). Milk proteins as vehicles for bioactives. Current Opinion in Colloid \& Interface Science, 15(1-2), 73-83. doi:10.1016/j.cocis.2009.11.002

Mehalebi, S., Nicolai, T., \& Durand, D. (2008). Light scattering study of heat-denatured globular protein aggregates. International Journal of Biological Macromolecules, 43, 129-135.

Mills, O. E. (1976). Effect of temperature on tryptophan fluorescence of beta-lactoglobulin B. Biochim Biophys Acta, 434(2), 324-332.

Moitzi, C., Donato, L., Schmitt, C., Bovetto, L., Gillies, G., \& Stradner, A. (2011). Structure of blactoglobulin microgels formed during heating as revealed by small-angle X-ray scattering and light scattering. Food Hydrocolloids, 25, 1766-1774.

Mudgal, P., Daubert, C. R., \& Foegeding, E. A. (2011). Kinetic study of b-lactoglobulin thermal aggregation at low pH. Journal of Food Engineering, 106, 159-165.

Nicolai, T., Britten, M., \& Schmitt, C. (2011). $\beta$-lactoglobulin and WPI aggregates: formation, structure and applications. Food Hydrocolloids, 25, 1945-1962.

Pham, T. T., Jaafar-Maalej, C., Charcosset, C., \& Fessi, H. (2012). Liposome and niosome preparation using a membrane contactor for scale-up. Colloids and Surfaces BBiointerfaces, 94, 15-21.

Qin, B. Y., Bewley, M. C., Creamer, L. K., Baker, H. M., Baker, E. N., \& Jameson, G. B. (1998). Structural basis of the Tanford transition of bovine â-lactoglobulin. Biochemistry, $1998 b(37), 14014-14023$.

Qin, B. Y., Creamer, L. K., Baker, E. N., \& Jameson, G. B. (1998). 12-Bromododecanoic acid binds inside the calyx of bovine $\beta$-lactoglobulin. FEBS Lett., 1998a(438), 272-278. 
Reynolds, J. A., \& Tanford, C. (1970). Binding of Dodecyl Sulfate to Proteins at High Binding Ratios. Possible Implications for the State of Proteins in Biological Membranes. National Academy of Sciences, 66(3), 1002-1007.

Ron, N., Zimet, P., Bargarum, J., \& Livney, Y. D. (2010). Beta-lactoglobulin-polysaccharide complexes as nanovehicles for hydrophobic nutraceuticals in non-fat foods and clear beverages. International Dairy Journal, 20(10), 686-693. doi::10.1016/j.idairyj.2010.04.001

Roy, V. K., Kumar, S., \& Gurusubramanian, G. (2012). Protein-structure, properties and their separation by SDSpolyacrylamide gel electrophoresis Sicencevision, 12(4), 170-181.

Sakurai , K., Oobatake , M., \& Goto, Y. (2001). Salt-dependent monomer-dimer equilibrium of bovine $\beta$-Lg at pH 3. Protein Science, 10, 2325-2335.

Sarkar, A., Goh, K. K. T., Singh, R. P., \& Singh, H. (2009). Behaviour of an oil-in -water emulsion stabilised by $\beta$-lactoglobulin in an in vivo gastric model. Food Hydrocolloids, 23, $1563-1569$.

Sawyer, L. (2002). beta-Lactoglobulin: Properties, structure and function. Journal of Dairy Science, 85(Supplement 1), 50.

Schokker, E. P., Singh, H., Pinder, D. N., \& Creamer, L. K. (2000). Heat-induced aggregation of b-lactoglobulin $A B$ at $\mathrm{pH}=2.5$ as influenced by ionic strength and protein concentration. International Dairy Journal, 10, 233-240.

Shpigelman, A., Cohen, Y., \& Livney, Y. D. (2012). Thermally-induced $\beta$-lactoglobulin-EGCG novehicles: loading, stability, sensory and digestive-release study. Food Hydrocolloids, 29, 57-67.

Sigma-Aldrich. (2017). 2-Mercaptoethanol $\geqslant 99.0 \%$ |Sigmaaldrich.com. Retrieved from 31 January 2017, http://www.sigmaaldrich.com/catalog/product/aldrich/m6250?lang=en\&region=GB

Somogyi, L. P. (2010). Caffeine Intake by the U.S. Population.

Tauliera, N., \& Chalikiana, T. V. (2001). Characterization of pH-induced transitions of $\beta$ lactoglobulin: ultrasonic, densimetric, and spectroscopic studies. Journal of Molecular Biology, 314(4), 873-889. 
788 Tumolo, T., Angnes, L., \& Baptista, M. S. (2004). Determination of the refractive index 789 increment $(\mathrm{dn} / \mathrm{dc})$ of

790 molecule and macromolecule solutions by surface plasmon resonance. Analytical $791 \quad$ Biochemistry, 333(2), 273-279.

792 Warren, J., \& Gordon, J. (1966). On the Refractive Indices of Aqueous Solutions of Urea. . The 793 Journal of Physical Chemistry, 70(1), 297-300.

794 Zeese, M., Huppertz, T., \& Kelly, A. (2008). Effect of high-pressure treatment on in-vitro 795 digestibility of $\beta$-lactoglobulin. Innovative Food Science and Emerging Technologies, 9, 796 62-69.

797 Zimet, P., \& Livney, Y. D. (2009). Beta-lactoglobulin and its nanocomplexes with pectin as 798 vehicles for omega-3 polyunsaturated fatty acids. Food Hydrocolloids, 23(4), 1120799 1126. doi:10.1016/j.foodhyd.2008.10.008

800 